\title{
Historical change in a Caribbean reef sponge community and long-term loss of sponge predators
}

\author{
Magdalena Łukowiak ${ }^{1, *}$, Katie L. Cramer ${ }^{2,3}$, Daniel Madzia ${ }^{1}$, Michael G. Hynes ${ }^{3}$, \\ Richard D. Norris ${ }^{2}$, Aaron O'Dea ${ }^{3}$ \\ ${ }^{1}$ Institute of Paleobiology, Polish Academy of Sciences, 00-818 Warsaw, Poland \\ ${ }^{2}$ Center for Marine Biodiversity and Conservation, Scripps Institution of Oceanography, University of California San Diego, \\ La Jolla, CA 92093, USA \\ ${ }^{3}$ Smithsonian Tropical Research Institute, PO Box 0843-03092, Balboa, Republic of Panama
}

\begin{abstract}
Sponges are an ecologically important component of modern Caribbean coral reefs. However, little is known about the structure of sponge communities prior to the large-scale degradation of Caribbean reef ecosystems. Here we explore changes in the sponge community over the past millennium by analyzing the composition of sponge spicules from a sediment core collected from a lagoonal reef within the archipelago of Bocas del Toro, Caribbean Panama. The analysis reveals a change in spicule composition that began approximately $400 \mathrm{yr}$ ago. During this time, the share of monaxial spicules, belonging mostly to haplosclerid and axinellid sponges, decreased while the relative number of spherical spicules, found typically in Placospongia, Geodia, and some chondrillids, increased. These results were compared with previously published data on parrotfish, corals, and reef accretion rates obtained from the same core. The increased share of spherical spicules did not correlate with contemporaneous declines in the abundance of parrotfish (determined from fish teeth) or with trends in the relative abundance of dominant coral species (determined from coral skeletal remains) but was weakly correlated with reef accretion rates (determined from sediment accumulation rates). Spicule morphogroup diversity and evenness increased over the past $\sim 400 \mathrm{yr}$, suggesting community changes were not due to reef environments becoming less habitable for reef sponges. Although not tested directly, the increase in spherical spicules may be due to declines in the abundance of sea turtles that preferentially feed on sponges that contain these spicule types.
\end{abstract}

KEY WORDS: Sponge spicules $\cdot$ Hawksbill turtles $\cdot$ Placospongia $\cdot$ Geodia $\cdot$ Bocas del Toro

\section{INTRODUCTION}

Sponges are important components of coral reef ecosystem stability and diversity (e.g. Wulff 1984, Díaz \& Rützler 2001, de Goeij et al. 2017). As suspension feeders, sponges link benthic and pelagic environments (Wulff 2006, Bell 2008, Maldonado et al. 2012) and transfer dissolved organic matter to higher trophic levels (de Goeij et al. 2013). At the same time, sponges are a source of food for many reef inhabitants such as fishes and turtles (Meylan 1988, Dunlap

\footnotetext{
${ }^{*}$ Corresponding author: mlukowiak@twarda.pan.pl
}

\& Pawlik 1996, Pawlik 1998, 2011, León \& Bjorndal 2002, Loh \& Pawlik 2014).

As the abundance of Caribbean reef-building corals has been reduced by $50 \%$ over the past few decades (Jackson et al. 2014), sponges have become the dominant benthic organisms on many Caribbean reefs (McClanahan et al. 1999, Loh et al. 2015). Fluctuations in sea temperature and chemistry, diseases, and water pollution are thought to be among the main factors responsible for the rise in sponge dominance $\left(\mathrm{D}^{\prime} \mathrm{Croz}\right.$ et al. 2005, Easson et al. 2015). Although detailed moni-

() The authors 2018. Open Access under Creative Commons by Attribution Licence. Use, distribution and reproduction are unrestricted. Authors and original publication must be credited. 
toring of Caribbean reefs did not begin until the 1980s, human activities have been affecting reef health for much longer (Jackson et al. 2001, Pandolfi et al. 2003, Cramer et al. 2012). The preserved remains of reef organisms (subfossils) provide longterm ecological records that can reveal premonitoring, prehistorical, and prehuman changes in reef community composition and environments (Kosnik \& Kowalewski 2016, Cramer et al. 2017, 2018, O'Dea et al. 2017). However, most studies documenting long-term changes in reef communities from subfossils have focused on corals (e.g. Aronson et al. 2004, Pandolfi et al. 2005, Edmunds 2013), with little attention paid to other reef inhabitants (Roopnarine \& Dineen 2018).

Alterations in reef food webs due to fishing appear to have had a considerable influence on modern Caribbean reef sponge communities. Top-down processes driven by predators control sponge community structure (Pawlik et al. 2013, 2018), and the removal of predators alters reef sponge distribution (Loh \& Pawlik 2014, Wooster et al. 2017). However, the role of bottom-up processes (nutrients) is also an area of active debate (see review in Pawlik et al. 2018). Sponge predators uniformly tend to preferentially consume palatable sponge taxa and avoid chemically defended ones (Pawlik 2011). This pattern has led some researchers to hypothesize that the loss of predators of more palatable sponge taxa from overfishing may have resulted in an increase of these sponges on modern reefs (Pawlik et al. 2018). This hypothesis has not been tested using historical subfossil evidence so far.

We analyzed the composition of sponge spicule assemblages preserved within a reef sediment core collected in Bocas del Toro, Caribbean Panama, to explore sponge community response following the rise of intensified human activity in the region over the past millennium (Cramer 2013). We discuss the possible impact of the removal of sponge predators on the changes we observe in sponge spicule composition. The study presented here is part of a broader project of long-term change in entire reef ecosystems in Bocas del Toro analyzing fish, coral, urchin, mollusc, and benthic foraminifera subfossils of the Bahía del Almirante (Cramer et al. 2017, 2018). The sponge spicule data obtained during this study are compared here with parrotfish and coral data obtained from the same core and published previously (Cramer et al. 2017) and historical turtle abundance data from previous studies (Wake et al. 2013, Pawlik et al. 2018). We utilize our simultaneous record of long-term change in multiple reef components to determine whether observed trends in sponge community composition are related to abundance changes in what some researchers have hypothesized to be major sponge predators (parrotfish and hawksbill turtles) (e.g. Pawlik 1998) as well as changes in habitat condition (abundance of common coral species and overall reef accretion rate).

\section{MATERIALS AND METHODS}

\section{Study area}

The Bocas del Toro archipelago is a geographically complex area composed of numerous islands surrounded by extensive mangrove systems and fringing and patch reefs (Fig. 1 $\mathrm{A}_{i} \mathrm{D}^{\prime} \mathrm{Croz}$ et al. 2005, Cramer 2013). Modern reef ecosystems began to accrete around $8000 \mathrm{yr}$ ago following postglacial sea level rise (Coates et al. 2005) and started to experience anthropogenic impact as early as $250 \mathrm{yr}$ ago (Cramer et al. 2017). More recent changes were first noted by surveys conducted in the 1980s (Lessios et al. 1984), with accelerated changes documented in subsequent decades (Guzmán \& Guevara 1998a,b, 1999, 2001, Seemann et al. 2014). Although the biomass and diversity of sponges often exceeds that of corals in Bocas del Toro (see supplementary material in Loh \& Pawlik 2014), there are currently no data on trends in sponge communities for this region.

\section{Reconstructing sponge community composition}

To track long-term change in sponge communities, we analyzed the composition of sponge spicule assemblages within a $305 \mathrm{~cm}$ long sediment core obtained from the Punta Donato patch reef $\left(9.35798^{\circ} \mathrm{N}, 82.36809^{\circ} \mathrm{W}\right.$; Fig. 1A). The reef core was composed primarily of corals, mollusc shells, and other carbonates in a sandy-muddy matrix. Details of the extraction and subsampling of this core are in Cramer et al. (2017). To provide a moderateresolution record of change in spicule composition, we analyzed spicule assemblages from 23 samples of $5 \mathrm{~cm}$ thickness along the length of the core (Fig. 1B). Although the larger study of millennial-scale, ecosystem-level change in Bocas del Toro involved the collection of 2 replicate cores from each of 3 reef sites in Bahía del Almirante, the Punta Donato site provided a high-resolution record from the historical period to the present (Cramer et al. 2017). To ensure that sufficient core sediments were preserved for analysis of other fossil groups, we focused on a single core from Punta Donato for our spicule analysis. Because of dif- 


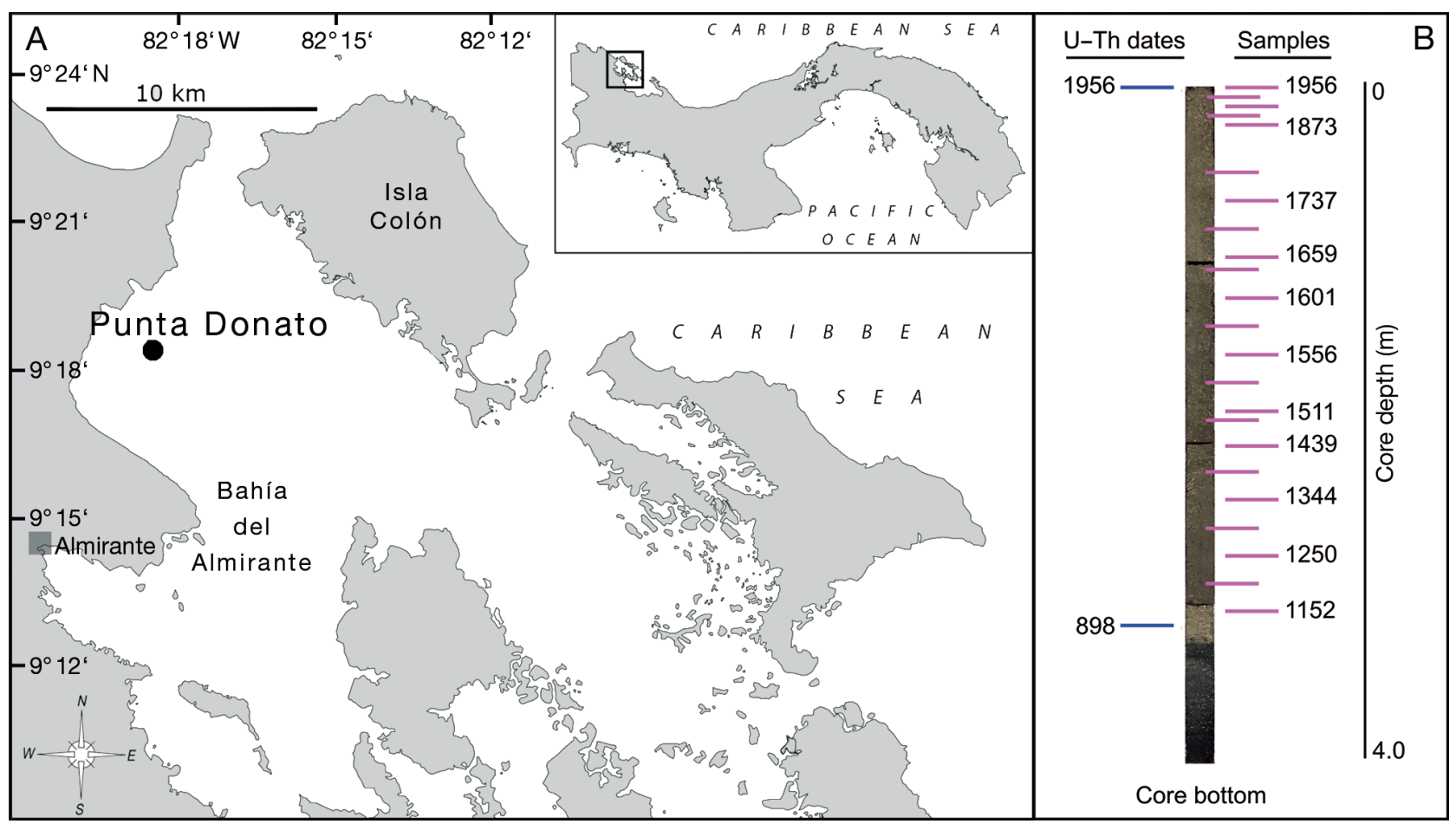

Fig. 1. (A) Coring location at Punta Donato reef in Bahía del Almirante, Bocas del Toro Province, Panama, and (B) reef matrix core analyzed for composition of sponge spicules, fish teeth, coral skeletal fragments, and reef accretion rates. Blue lines indicate the position along the length of the core from which U-Th dates were obtained from coral fragments; pink lines indicate the position along the length of the core from which sponge spicule composition was assessed. Numbers indicate dates of samples in year AD. Please see text for details of the estimation of sample dates located between U-Th-dated samples. Because of space limitations, dates are shown for only 11 of the 23 total samples. Modified from Cramer et al. 2017

fering sampling protocols across fossil groups, only 9 of the 23 samples analyzed for spicules also have data for corals and reef fish teeth (published in Cramer et al. 2017).

\section{Sample maceration}

Samples of approximately $50 \mathrm{~g}$ of reef matrix sediment were macerated using dilute hydrogen peroxide to remove organic matter and separate individual sponge spicules. Samples were heated on a hotplate to accelerate reactions, rinsed with water several times to remove all reaction by-products, and dried at $70^{\circ} \mathrm{C}$. Next, the samples were sieved to remove all sediments $>5 \mathrm{~mm}$ which did not contain sponge spicules. The residue was digested with $30 \%$ acetic acid to dissolve all calcium carbonate, resulting in the exclusion of 2 calcareous sponge species from our analyses (i.e. Clathrina primordialis and Leucetta floridana). Following rinsing, the remaining residue, consisting mostly of siliceous sponge spicules and inorganic silica particles, was dried. The spicule residue was laid out on a counting plate with a brush and counted under a stereomicroscope from randomly chosen $2 \times 2 \mathrm{~mm}$ square areas. Each spicule encountered was assigned to 1 of 10 morphological groups (Tables S1 \& S2 in the Supplement at www.int-res.com/articles/suppl/m601p127_supp.pdf, Figs. 2-4) until 1000 spicules were counted per sample. For further details, see Łukowiak et al. (2013), Łukowiak (2016), and the literature cited therein.

\section{Assessing timing of change in sponge communities}

Sample ages were estimated using uranium-thorium (U-Th) dating of coral skeletal fragments (Clark et al. 2012, Cramer et al. 2017). A highly constrained chronology was produced for 1 replicate core at Punta Donato, where $4 \mathrm{U}-\mathrm{Th}$ ages were obtained from the top $1 \mathrm{~m}$ of the core and 1 date from approximately every $0.5 \mathrm{~m}$ interval below that, yielding 6 ages total for the portion of the core that represents coral reef habitat (the bottom of the core represents soft-bottom habitat prior to reef formation; Cramer et al. 2017). From this core, accretion rates were estimated using linear interpolation between each pair 
of ages. For the second Punta Donato replicate core from which spicules were analyzed, 2 U-Th ages were obtained (1 each from the top and bottom of the section representing reef habitat; Fig. 1B). Sedimentation (reef accretion) rates from the well-dated core were linked with the replicate core by using the top age to constrain the sedimentation rate of the latter to that of contemporaneous periods of the former (for details, see Cramer et al. 2017). Because reef accretion rates were available for each sample, all samples analyzed for spicules contain an accretion estimate.

\section{Analysis of community change}

Temporal patterns in sponge spicule assemblages were assessed by computing the relative abundance (proportion of total number of spicules counted) of each of the 10 spicule morphotypes within each sample and then plotting these values for the most common groups (comprising $>1 \%$ of assemblage on aver- age). Temporal patterns were assessed across the time span representing the full core length using non-parametric locally weighted regression (loess)smoothed trendlines (Cleveland \& Devlin 1988). To assess general patterns across the full time series while capturing non-unidirectional fluctuations in the data, $90 \%$ of the time series was used to fit each local regression (smoothing parameter $=0.9$ ). Contemporary patterns in possible drivers of sponge composition-parrotfish abundance (proportion of fish teeth fossils positively identified as belonging to parrotfish) and reef accretion rates (mm of reef sediment accumulated per year, based on accretion rate estimates derived from U-Th dates as described in the previous subsection), both taken from Cramer et al. (2017) - were plotted alongside the relative abundance of dominant spicule type in assemblages. Temporal patterns in spicule morphogroup richness, diversity (measured as Shannon's diversity index $H$, shown in Eq. (1), where $p_{i}=$ proportion of spicules made up of the $i^{\text {th }}$ morphogroup and $S=$ total number

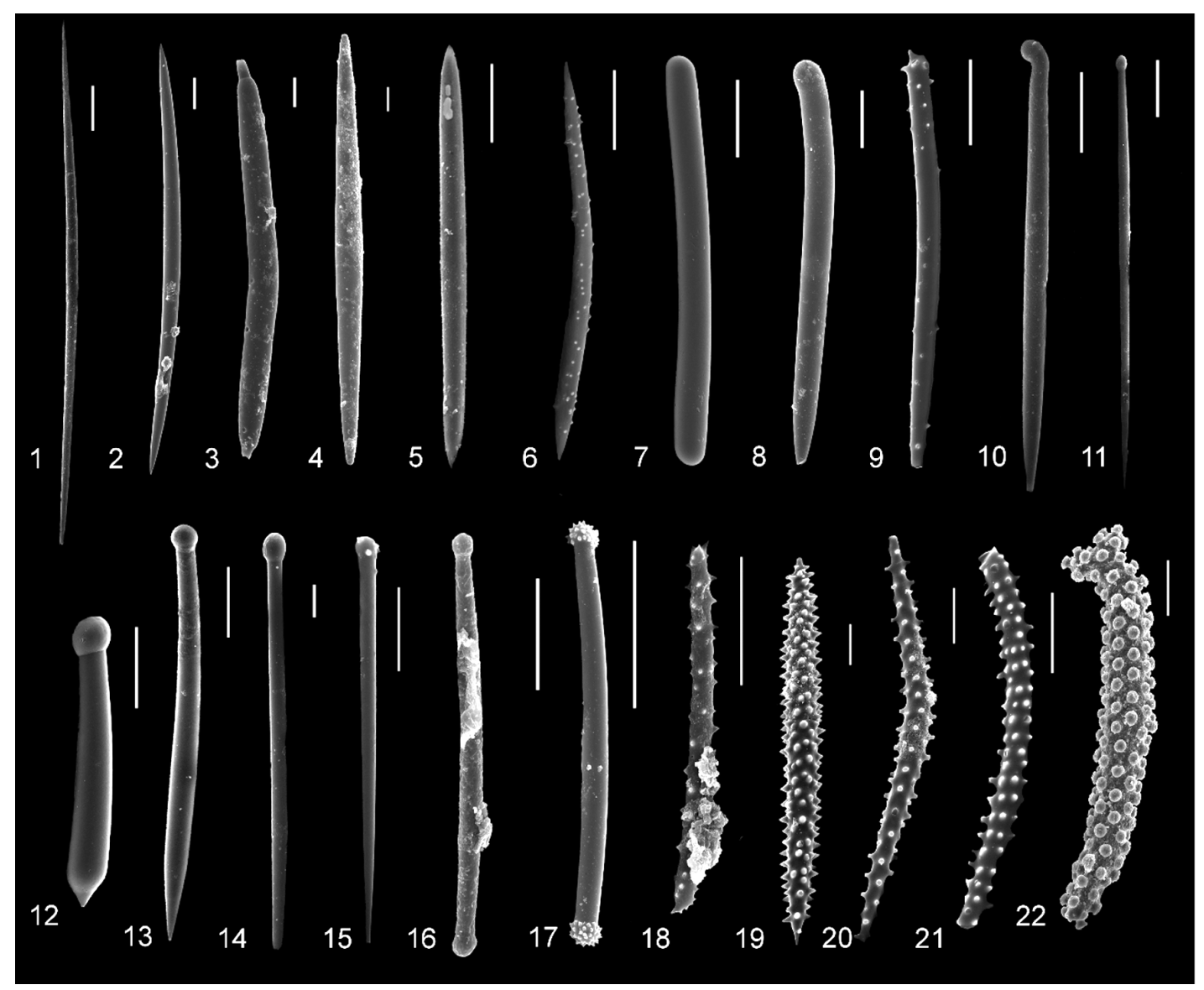

Fig. 2. Spicule morphotypes present in reef sediments of the studied area belonging to the following morphogroups: oxeas (1-5: oxeas, 6: acanthoxea, 7: strongyle, 8-10: styles), tylostyles (11-14: tylostyles), others (15: acanthostyle?; 16, 17: tylotes; 18-20: acanthoxeas; 21: acanthostrongyle; 22: diactine). Scale bars: 1-9, 11-16, 18-21, 22: $50 \mu \mathrm{m} ; 10,17: 100 \mu \mathrm{m}$ 


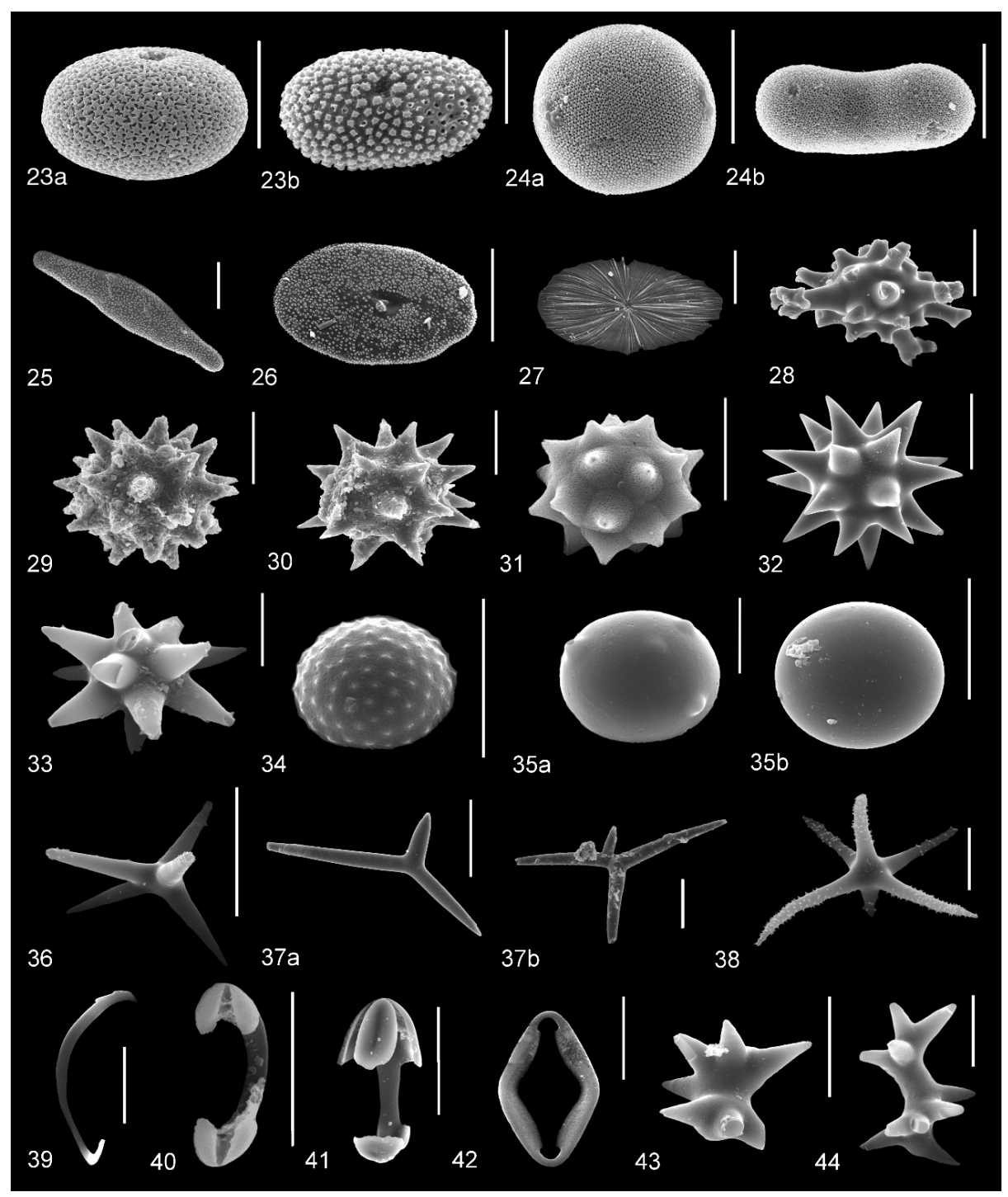

Fig. 3. Spicule morphotypes present in reef sediments of the studied area belonging to the following morphogroups: sterrasters/selenasters (23a,b: sterrasters; 24a,b: selenasters), aspidasters (25-27: aspidasters), spherasters/anthasters (28: anthaster, 29-34 spherasters), others (35a,b: spheres; 36, 37: streptoscleres; 38: hexactine; 39: sigma; 40: isochela; 41: anisochela; 42: clavidisc; 43, 44: spirasters). Scale bars: 23-25, 27-30, 32, 36, 39, $42: 50 \mu \mathrm{m} ; 26,37 \mathrm{a}$, b: $100 \mu \mathrm{m} ;$ 31, 33-35, 38, 40, 41, 43, 44: 25 $\mu \mathrm{m}$

of morphogroups in a sample, or richness), and evenness $(=H / \ln S)$ were also computed for each sample and plotted across the full time series (Shannon \& Weaver 1949).

$$
H=a b s \sum_{i=1}^{s} p_{i} \times \ln \left(p_{i}+0.001\right)
$$

\section{RESULTS}

\section{Sponge spicule composition and preservation}

Ten morphogroups were designated from the spicule assemblage within the Punta Donato core: amphitriaenes, aspidasters, calthrops, oxeas, sterrasters/selenasters, spherasters/anthasters, triaenes, triods, tylostyles, and an 'others' group which represented other, uncommon morphogroups (Figs. 2-4, Table S1). This assemblage captures the overall morphological variability of the siliceous spicule material observed in bulk sediment samples within Bahía del Almirante (e.g. Łukowiak et al. 2013). Oxeas (Fig. 2.1-2.10) and sterrasters/selenasters (Fig. 3.23-3.24) were consistently the most abundant morphogroups throughout the core, accounting for 87 and $9 \%$, respectively, of all spicules across all samples (Table S1, Fig. 5). Spheraster/anthaster (Fig. 


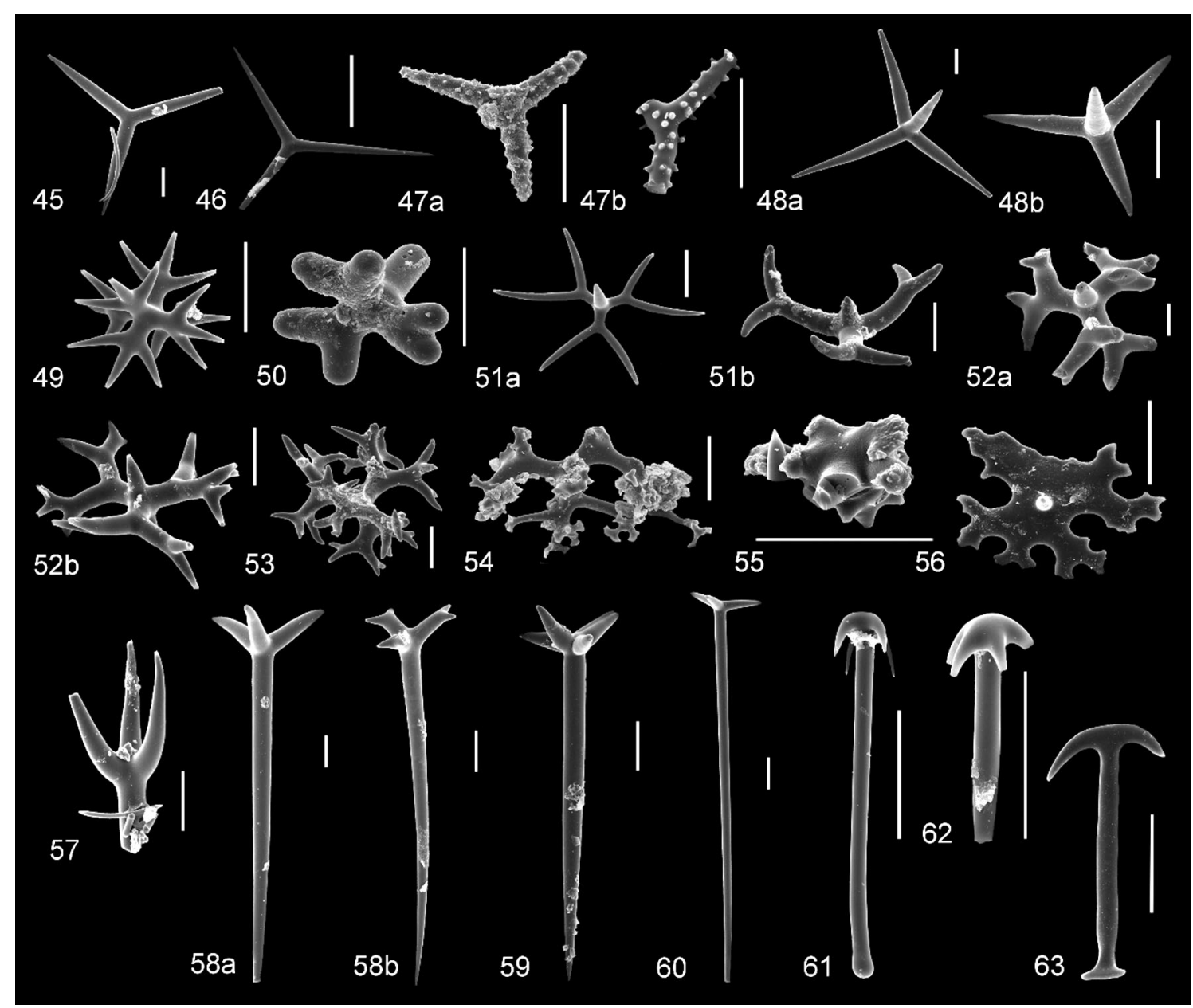

Fig. 4. Spicule morphotypes present in reef sediments of the studied area belonging to the following morphogroups: triods (45-47b: triods), calthrops (48a,b: calthrops), amphitriaenes (49: amphitriaene), triaenes (50-53: short-shafted triaenes, 57-60: long-shafted triaenes), others (54: clone; 55: unidentified spicule type; 56: phyllotriaene; 61, 62: cladotylotes; 63: anchor). Scale bars: $100 \mu \mathrm{m}$

3.28-3.34) and tylostyle (Fig. 2.11-2.14) morphogroups were subdominant (comprising $>1 \%$ on average). Spicule preservation, as assessed by physical appearance, was uniform along the entire length of the core. There was no apparent difference (as visually estimated across all samples) in the frequency of broken spicules within samples over time and all spicule morphogroups were observed in all samples, suggesting little bias in preservation over time.

\section{Long-term change in sponge assemblages}

The most notable change is the decrease in the relative abundance of monaxial spicules (oxeas) and increase in spherical spicules (sterrasters/selenasters) over time beginning approximately 400 yr ago
(Fig. 5A). From 1600 to 1954 AD, oxeas declined from 94 to $67 \%$ of spicules while sterrasters/selenasters increased from 3 to $29 \%$ of spicules (Fig. 5A). Although parrotfish abundance and reef accretion rates also followed this general decline over the past 400 yr (Fig. $5 \mathrm{C}, \mathrm{D})$, the relative abundance of spherical spicules was not correlated with the relative abundance of parrotfish teeth and only weakly correlated with reef accretion rates (Fig. 6A,B). Relative abundance of spherical spicules was not correlated with the relative abundance of either of the most common coral species found in the Punta Donato core, low-relief branching Madracis mirabilis and Porites spp. (Fig. 6C,D).

Components of spicule morphogroup diversityrichness and evenness - showed contrasting patterns during the period of observed change in spicule assemblage encompassing the past 4 centuries. Richness per sample fluctuated from 4 to 9 morphogroups over 


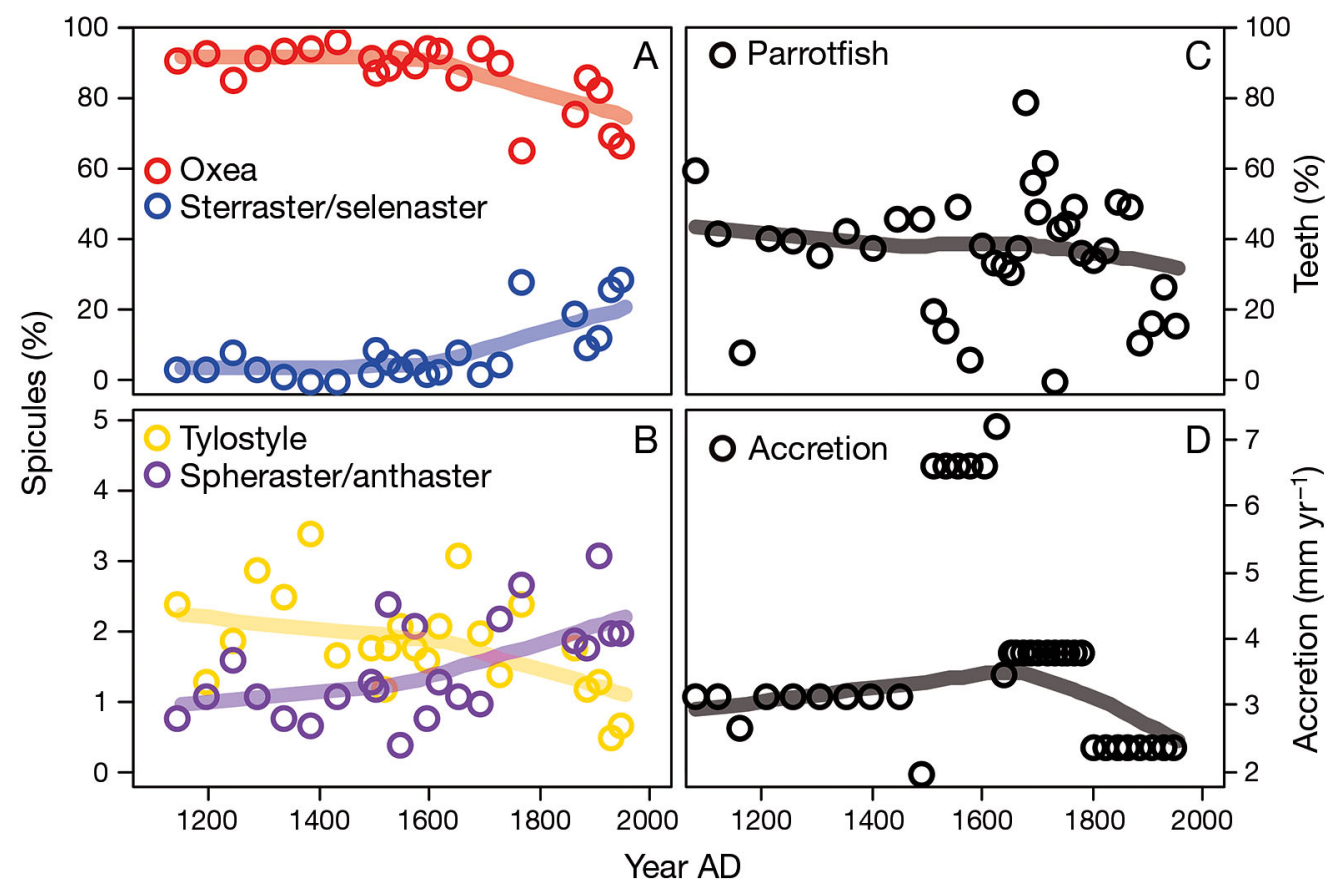

Fig. 5. Relative abundance of (A) dominant and (B) subdominant sponge spicule morphotypes, (C) parrotfish teeth, and (D) reef accretion rates in Punta Donato core. Percent parrotfish teeth computed from all teeth found in sediments $>63$ um; accretion rates determined from linear interpolation of U-Th ages from well-dated Punta Donato replicate core (see Cramer et al.

2017). Trendlines from loess-smoothed estimates; smoothing parameter $=0.9$
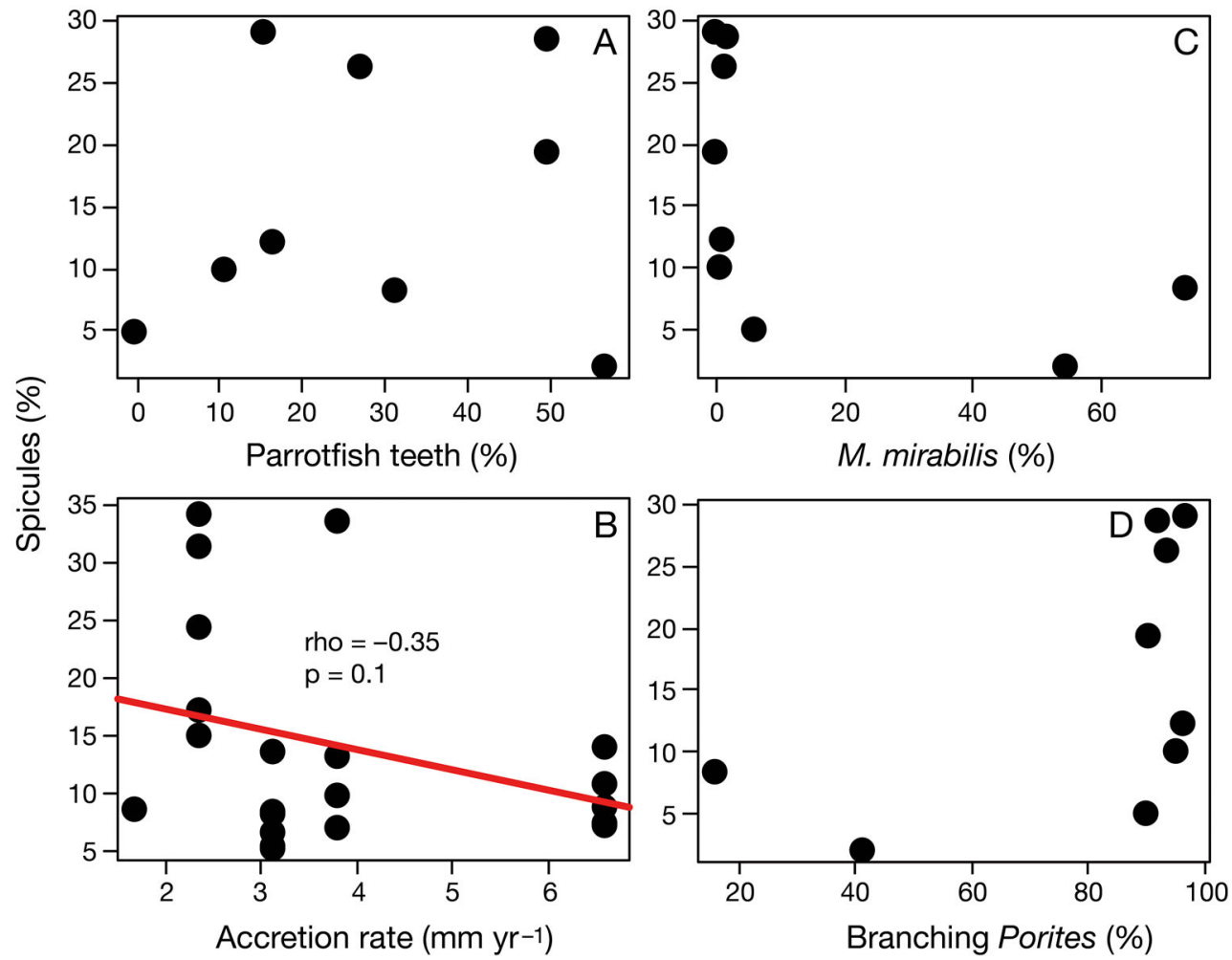

Fig. 6. Relative abundance of spherical spicules (sterrasters/selenasters) versus potential drivers of sponge spicule composition: (A) parrotfish teeth, (B) reef accretion rates, (C) Madracis mirabilis coral, (D) branching Porites coral. Trendline indicates significant (Pearson) correlation at $\mathrm{p}=0.1$ level 


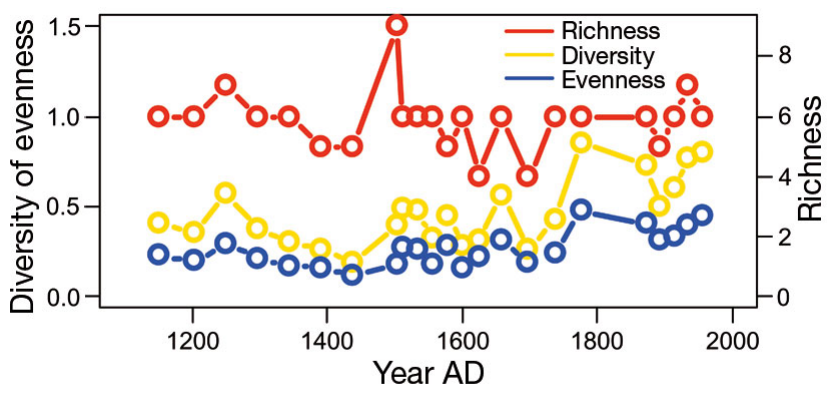

Fig. 7. Diversity, richness, and evenness of dominant and subdominant sponge spicule morphogroups through time. Shannon-Wiener $H$ used as diversity metric

the last millennium and did not show a clear pattern over the past $400 \mathrm{yr}$ (Fig. 7), while evenness remained stable during the first $600 \mathrm{yr}$ of the time series (from $\sim 1000$ to $1600 \mathrm{AD}$ ) and then gradually increased from 1600 to 1956 AD. The Shannon-Wiener diversity index followed a similar pattern as evenness.

\section{DISCUSSION}

\section{Assessing sponge community composition from spicules}

Because sponge species can include multiple spicule morphotypes, it is often impossible to assign spicule types to a single taxonomic group. However, spherical spicules belonging to the sterraster/selenaster and spheraster/anthaster groups can be confidently assigned to a small number of taxa present in the Bocas del Toro region, assuming there has been no extinction in the last $\sim 2000$ yr. Sterrasters and selenasters dominate in Geodia and Placospongia, respectively, while spherasters and anthasters can be found in Chondrilla, Placospongia, Tethya, and Diplastrella (Table S1). In addition, the spicules falling within the oxea morphogroup (i.e. all monaxial spicule morphotypes except for tylostyles) are characteristic for poecilosclerids, astrophorids, halichondrids, spirophorins, bubarids, and tethyids. However, they dominate only in haplosclerids (including Callyspongia, Niphates, and Oceanapia) and axinellids. Tylostyles appear in clionaids, hadromerids, and some poecilosclerids (Table S1).

\section{Potential drivers of long-term sponge community change}

Although we are not able to directly track the full taxonomic composition of past sponge communities from spicule assemblages, we are able to gather insight into changes in sponge taxa that are preferentially eaten by various predators. Among sponges present in the studied area, those that are most palatable for fishes bear both spherical and monaxial spicules. Parrotfish preferentially feed on Placospongia, Geodia, and Callyspongia (Pawlik et al. 1995) and angelfish on Callyspongia, Iotrochota, and Chondrilla (Randall \& Hartman 1968). Hawksbill turtles, in turn, feed mostly on sponges that bear almost exclusively spherical spicules of the sterraster/ selenaster and spheraster/anthaster morphogroups, i.e. Placospongia, Geodia, and Chondrilla (Pawlik et al. 2018). Thus, our spicule record provides a possible proxy for long-term change in sponge predator abundance, particularly in the absence of other explanations for change in the spicule composition of reef sediments.

We hypothesize that the observed decline in sponges bearing monaxial spicules (mostly haplosclerids and axinellids) and rise of sponges bearing spherical spicules (e.g. Placospongia, Geodia, and Chondrilla) since $1600 \mathrm{AD}$ is best explained by the loss of a major sponge predator, the hawksbill turtle Eretmochelys imbricata, from historical overfishing. The selective feeding of hawksbill turtles on sponge taxa bearing spherical spicules has been shown to play an important role in structuring the reef sponge community and limiting the distribution of some Caribbean sponges (Meylan 1988, Dunlap \& Pawlik 1996, Pawlik 1998, León \& Bjorndal 2002, Pawlik et al. 2018). Hawksbill turtle populations have been greatly reduced in the Caribbean by overfishing since European contact, with their abundance reduced to between 1 and $10 \%$ of preColumbian levels (Parsons 1972, Meylan \& Donnelly 1999, McClenachan et al. 2006). Archeological data from Bocas del Toro show that exploitation of sea turtles by indigenous populations predates European contact, intensifying between 1100 and 1400 AD (Wake et al. 2013). Turtle exploitation continued to increase after first contact with Europeans; old historical notes, dating back as far as 1684, suggest apparent attempts to use hawksbill turtles for their meat (McClenachan et al. 2006, Pawlik et al. 2018). However, for the next 2 centuries, their consumption was likely limited because their meat was generally considered toxic and not particularly edible (McClenachan et al. 2006). Nevertheless, the turtle meat industry had already been established at the time, and hawksbills were being hunted also for their fat, eggs, and shells (Wake et al. 2013). 
In pre-Columbian and around first contact times, when hawksbills were presumably still abundant, the ratio of turtles to palatable sponges may have forced hawksbills to feed on both chemically undefended and defended sponge species, which could have affected the taste of their meat. Around 1900, however, the meat of hawksbill turtles was already considered edible and nourishing (McClenachan et al. 2006). This shift in the tastefulness of the turtle meat is suggested to be due to increased availability of palatable sponge species following declines in turtle predation.

Fishes, including parrotfish, feed on Caribbean sponges as well (Dunlap \& Pawlik 1996). However, they are not considered major sponge predators in this region (Randall 1967). Although the number of parrotfish apparently began declining as early as 300 yr ago at the Punta Donato core (Cramer et al. 2017), we did not find a correlation between abundance of parrotfish teeth and spherical spicules. This may be because the sponge species preferred by parrotfish (i.e. Placospongia, Geodia, and Callyspongia; see Pawlik et al. 1995) bear spicules falling within both the monaxial and spherical morphogroups. As such, our data cannot test the hypothesis that overfishing of parrotfish was a driver of observed changes in the sponge community (Pawlik et al. 2013, Loh \& Pawlik 2014 ).

Sponge spicule morphogroup evenness and diversity increased over the past $\sim 400 \mathrm{yr}$, suggesting that reef environments became more favourable for sponges with mineralized spicules at this reef. This timing coincides with a change in the dominant reefbuilding coral species at Punta Donato, from branching Porites spp. to Madracis mirabilis, that was also initiated approximately 500 yr ago (Cramer et al. 2017). Notably, the relative abundance of spherical spicules continued to increase over the past $200 \mathrm{yr}$ despite resumption in dominance of branching Porites corals during this period. These trends suggest that the observed shift in dominant morphogroup, from less palatable sponges bearing oxeas to more palatable sponges with sterrasters/selenasters, is not primarily due to a change in reef coral community composition but instead relates to prey release following the overfishing of sponge predators such as hawksbill turtles.

\section{Potential biases}

Several taphonomic filters could have affected the composition of sponge spicule assemblages in our study. First, we were only able to analyze spicules from taxa that produce an opal mineral skeleton (170 of 198 species, Table 1 in Łukowiak 2016). Although this represents only $86 \%$ of taxa, such groups represent over $40 \%$ of total living sponge biomass in Bocas del Toro today (Łukowiak et al. 2013). Second, small spicules less than $25 \mu \mathrm{m}$ in size were not included in our analyses because of their poor preservation potential. For a more extensive discussion regarding caveats related to the assessment of loose sponge spicules and their relationship to the living sponge community, see Łukowiak et al. (2013). Third, monaxial spicules (oxeas, styles, and strongyles) are more likely to be physically damaged because of their thin and elongated morphology than more robust spherical types (selenasters, sterrasters, and spherasters) (Rützler \& Macintyre 1978). Thus, spherical spicules may be generally overrepresented in our samples. However, we observed that the proportion of broken spicules did not change significantly over time and the general preservation of spicules was continually excellent, even in the oldest samples, suggesting low levels of selective dissolution. Moreover, we found that the relative abundance of the more delicate monaxial spicules was greater in older not younger samples, suggesting that breakage of fragile spicules did not significantly bias our results (Fig. 6). Thus, our spicule assemblage accurately records long-term changes in reef sponge community composition in Bocas del Toro that may be related to historical overfishing of sea turtles. This study highlights the unique ability of the paleoecological record to detect alterations in reef ecosystems that occurred centuries before modern reef surveys, providing valuable insights into the anthropogenic mechanisms of the recent changes of these systems.

Acknowledgements. We thank all the people involved in collecting and processing the material, especially A. Jagtap (Northeastern University), B. De Gracia and F. Rodriguez (Smithsonian Tropical Research Institute), and all the team at the Bocas Research Station. Thanks are also due to A. Pisera (Institute of Paleobiology, Polish Academy of Sciences) for fruitful discussions during its preparation. We thank J. Mate and the Authority of Aquatic Resources of Panama for facilitating and providing collection permits and 3 anonymous reviewers for their constructive comments. Finally, M.Ł. and D.M. thank Milan Madzia for his eternal patience during the last phases of the preparation of the manuscript. This work was supported by the National Science Centre (NCN) Poland Grant No. 2013/09/D/ST10/ 04050 to M.モ., a Smithsonian Tropical Research Institute Short Term Fellowship (2011) to M.Ł., and the PalSIRP Sepkoski Grant (2011) to M.乇. The National System of Investigators (SNI) of SENACYT supported A.O. 


\section{LITERATURE CITED}

Aronson RB, MacIntyre IG, Wapnick CM, O'Neill MW (2004) Phase shifts, alternative states, and the unprecedented convergence of two reef systems. Ecology 85: 1876-1891

Bell JJ (2008) Functional roles of sponges. Estuar Coast Shelf Sci 79:341-353

Clark TR, Zhao JX, Feng YX, Done T, Jupiter S, Lough J, Pandolfi JM (2012) Spatial variability of initial ${ }^{230} \mathrm{Th} /{ }^{232} \mathrm{Th}$ in modern Porites from the inshore region of the Great Barrier Reef. Geochim Cosmochim Acta 78: 99-118

* Cleveland WS, Devlin SJ (1988) Locally weighted regression: an approach to regression analysis by local fitting. J Am Stat Assoc 83:596-610

Coates AG, Mcneill DF, Aubry MP, Berggren WA, Collins LS (2005) An introduction to the geology of the Bocas del Toro Archipelago, Panama. Carib J Sci 41:374-391

Cramer KL (2013) History of human occupation and environmental change in western and central Caribbean Panama. Bull Mar Sci 89:955-982

* Cramer KL, Jackson JB, Angioletti CV, Leonard-Pingel J, Guilderson TP (2012) Anthropogenic mortality on coral reefs in Caribbean Panama predates coral disease and bleaching. Ecol Lett 15:561-567

* Cramer KL, O'Dea A, Clark TR, Zhao JX, Norris RD (2017) Prehistorical and historical declines in Caribbean coral reef accretion rates driven by loss of parrotfish. Nat Commun 8:14160

K Cramer KL, O'Dea A, Carpenter C, Norris RD (2018) A 3000 year record of Caribbean reef urchin communities reveals causes and consequences of long-term decline in Diadema antillarum. Ecography 41:165-173

D'Croz L, Del Rosario JB, Gondola P (2005) The effect of fresh water runoff on the distribution of dissolved inorganic nutrients and plankton in the Bocas del Toro Archipelago, Caribbean Panama. Caribb J Sci 41: 414-429

de Goeij JM, van Oevelen D, Vermeij MJA, Osinga R, Middelburg JJ, de Goeij AFPM, Admiraal W (2013) Surviving in a marine desert: the sponge loop retains resources within coral reefs. Science 342:108-110

de Goeij JM, Lesser MP, Pawlik JR (2017) Nutrient fluxes and ecological functions of coral reef sponges in a changing ocean. In: Carballo JL, Bell JJ (eds) Climate change, ocean acidification and sponges: impacts across multiple levels of organization. Springer, Cham, p 373-410

Díaz MC, Rützler K (2001) Sponges: an essential component of Caribbean coral reefs. Bull Mar Sci 69:535-546

Dunlap M, Pawlik JR (1996) Video-monitored predation by Caribbean reef fishes on an array of mangrove and reef sponges. Mar Biol 126:117-123

Easson CG, Matterson KO, Freeman CJ, Archer SK, Thacker RW (2015) Variation in species diversity and functional traits of sponge communities near human populations in Bocas del Toro, Panama. PeerJ 3:e1385

Edmunds PJ (2013) Decadal-scale changes in the community structure of coral reefs of St. John, US Virgin Islands. Mar Ecol Prog Ser 489:107-123

Guzmán HM, Guevara CA (1998a) Arrecifes coralinos de Bocas del Toro, Panam: I. Distribución, estructura, y estado de conservación de los arrecifes de las islas de Bastimentos, Solarte, Carenero y Colon. Rev Biol Trop 46:601-623
Guzmán HM, Guevara CA (1998b) Arrecifes coralinos de Bocas del Toro, Panamá: II. Distribución, estructura, y estado de conservación de los arrecifes de las islas de Bastimentos, Solarte, Carenero y Colon. Rev Biol Trop 46:889-912

Guzmán HM, Guevara CA (1999) Arrecifes coralinos de Bocas del Toro, Panamá: III. Distribución, estructura, y estado de conservación de los arrecifes de las islas Pastores, Cristobal, Popa, y Cayo Agua. Rev Biol Trop 47: 659-676

*Guzmán HM, Guevara CA (2001) Arrecifes coralinos de Bocas del Toro, Panamá: IV. Distribución, estructura y estado de conservación de los arrecifes continentales de Península Valiente. Rev Biol Trop 49:53-66

Jackson JBC, Kirby MX, Berger WH, Bjorndal KA and others (2001) Historical overfishing and the recent collapse of coastal ecosystems. Science 293:629-637

Jackson JBC, Donovan MK, Cramer KL, Lam VV (2014) Status and trends of Caribbean coral reefs: 1970-2012. Global Coral Reef Monitoring Network, IUCN, Gland

Kosnik MA, Kowalewski M (2016) Understanding modern extinctions in marine ecosystems: the role of palaeoecological data. Biol Lett 12:20150951

*León YM, Bjorndal KA (2002) Selective feeding in the hawksbill turtle, an important predator in coral reef ecosystems. Mar Ecol Prog Ser 245:249-258

Kessios HA, Robertson DR, Cubit JD (1984) Spread of Diadema mass mortality through the Caribbean. Science 226:335-337

* Loh TL, Pawlik JR (2014) Chemical defenses and resource trade-offs structure sponge communities on Caribbean coral reefs. Proc Natl Acad Sci USA 111:4151-4156

Koh TL, McMurray SE, Henkel TP, Vicente J, Pawlik JR (2015) Indirect effects of overfishing on Caribbean reefs: sponges overgrow reef-building corals. PeerJ 3:e901

Łukowiak M (2016) Spicular analysis of surficial sediments as a supplementary tool for studies of modern sponge communities. Helgol Mar Res 70:5

毛ukowiak M, Pisera A, O'Dea A (2013) Do spicules in sediments reflect the living sponge community? A test in a Caribbean shallow water lagoon. Palaios 28:373-385

* Maldonado M, Ribes M, van Duyl FC (2012) Nutrient fluxes through sponges: biology, budgets, and ecological implications. Adv Mar Biol 62:113-182

* McClanahan TR, Aronson RB, Precht WF, Muthiga NA (1999) Fleshy algae dominate remote coral reefs of Belize. Coral Reefs 18:61-62

* McClenachan L, Jackson JBC, Newman MJH (2006) Conservation implications of historic sea turtle nesting beach loss. Front Ecol Environ 4:290-296

Meylan A (1988) Spongivory in hawksbill turtles: a diet of glass. Science 239:393-395

Meylan A, Donnelly M (1999) Status justification for listing the hawksbill turtle (Eretmochelys imbricata) as critically endangered on the 1996 IUCN Red List of Threatened Animals. Chelonian Conserv Biol 3:200-224

\%'Dea A, Dillon E, Altieri A, Lepore M (2017) Look to the past for an optimistic future. Conserv Biol 31: 1221-1222

* Pandolfi JM, Bradbury RH, Sala E, Hughes TP and others (2003) Global trajectories of the long-term decline of coral reef ecosystems. Science 301:955-958

* Pandolfi JM, Jackson JBC, Baron N, Bradbury RH and others (2005) Are US coral reefs on the slippery slope to slime? Science 307:1725-1726 
Parsons JJ (1972) The hawksbill turtle and the tortoiseshell trade. In: Etudes de geographie tropicale offertes a Pierre Gourou. Mouton, Paris, p 45-60

Pawlik JR (1998) Coral reef sponges: Do predatory fishes affect their distribution? Limnol Oceanogr 43:1396-1399

Pawlik JR (2011) The chemical ecology of sponges on Caribbean reefs: natural products shape natural systems. Bioscience 61:888-898

Pawlik JR, Chanas B, Toonen RJ, Fenical W (1995) Defenses of Caribbean sponges against predatory reef fish. I. Chemical deterrency. Mar Ecol Prog Ser 127:183-194

Pawlik JR, Loh TL, McMurray SE, Finelli CM (2013) Sponge communities on Caribbean coral reefs are structured by factors that are top-down, not bottom-up. PLOS ONE 8: e62573

Pawlik JR, Loh TL, McMurray SE (2018) A review of bottomup vs. top-down control of sponges on Caribbean forereefs: what's old, what's new, and future directions. PeerJ 6:e4343

Randall JE (1967) Food habits of reef fishes of the West Indies. Stud Trop Oceanogr 5:665-847

Randall JE, Hartman WD (1968) Sponge-feeding fishes of the West Indies. Mar Biol 1:216-225

Roopnarine PD, Dineen AA (2018) Coral reefs in crisis: the

Editorial responsibility: Joseph Pawlik, Wilmington, North Carolina, USA reliability of deep-time food web reconstructions as analogs for the present. In: Tyler CL, Schneider CL (eds) Marine conservation paleobiology. Top Geobiol, Vol 47. Springer, Cham, p 105-141

Rützler K, Macintyre I (1978) Siliceous sponge spicules in coral reef sediments. Mar Biol 49:147-159

* Seemann J, González CT, Carballo-Bolaños R, Berry K, Heiss GA, Struck U, Leinfelder RR (2014) Assessing the ecological effects of human impacts on coral reefs in Bocas del Toro, Panama. Environ Monit Assess 186: 1747-1763

Shannon CE, Weaver W (1949) The mathematical theory of communication. University of Illinois Press, Urbana, IL

Wake TA, Doughty DR, Kay M (2013) Archaeological investigations provide late Holocene baseline ecological data for Bocas del Toro, Panama. Bull Mar Sci 89:1015-1035

*Wooster MK, Marty MJ, Pawlik JR (2017) Defense by association: sponge-eating fishes alter the small-scale distribution of Caribbean reef sponges. Mar Ecol 38:e12410

*Wulff JL (1984) Sponge-mediated coral reef growth and rejuvenation. Coral Reefs 3:157-163

*Wulff JL (2006) Rapid diversity and abundance decline in a Caribbean coral reef sponge community. Biol Conserv 127:167-176

Submitted: November 9, 2017; Accepted: July 10, 2018

Proofs received from author(s): August 1, 2018 